\title{
The Root of Indian Communication Theory in the Rig Veda: Practical Vedānta
}

Anne Melfi

\begin{abstract}
What is the source of the power of speech and eloquence and fulfillment in life? Though communication and rhetoric departments in most Indian universities have been focusing their teaching and research agendas on Western models, a growing body of scholarship is developing communication theory that approaches the big questions from an Indian perspective, drawing on traditional sources (Adhikary, 2014), which claim Veda as their ultimate source. This paper explores the Vedic worldview on speech and communication proclaimed in the Richo Akśare verse of the Rig Veda, and others, drawing on sage Bhartṛhari (c. 450-500 CE), Maharishi Mahesh Yogi $(1975 ; 1971)$, and Sanskrit scholars of the philosophy of language, who reference these hymns. They describe a Vedic cosmology of speech that bears striking resemblance to the universe according to string theory of quantum physics. The science serves to corroborate the premise of Vedic levels-of-speech theory that the universe is structured and governed by laws of nature/language of nature from within an unmanifest unified field of all the laws of nature, which Rig Veda 1.164 calls Parā and identifies as consciousness. This inquiry helps to illuminate how speech is Brahman, the source and goal of understanding, eloquence, and fulfillment. The Vedic texts enjoin the sanātana dharma of yoga, opening awareness to the transcendental source of
\end{abstract}


speech. I conclude that Vedic communication theory embedded in the hymns is integral to practical Vedanta. As Muktitkā Upanișad 1.9 proclaims: "As oil is present in a sesame seed, so Vedānta is present in the Veda."

Keywords: Vedanta, Indian communication theory, levels of speech, Rig Veda 1.164.39, Vedic rhetoric

\section{The Root of Indian Communication Theory in the Rig Veda: Practical Vedānta}

The basis of Vedic-based communication theory is integral to Vedanta, as the Vedic hymns and commentaries suggest. Funnily enough, some commentaries consider the Vedas and Vedānta to have opposing views of reality since the Vedas feature a multiplicity of gods while Vedānta gives a unitary perspective, Brahman. The binary is a false one, an error in logic analogous to a claim the fact that there is a multitude of words contradicts the notion of speech, that dynamic unity of all words. Speech is Brahman in the Vedic view. Within the hymns can be found a vision of what could be called in hindsight "practical Vedānta," the practical benefits of living the state of knowledge and experience called Brahman. This paper finds the theme within certain hymns on the field of speech, which verify what the Muktitkā Upanișad (1.9) proclaims: "As oil is present in the sesame seed, so Vedānta is present in the Veda." To be fair, the unitary vision can be elusive amidst the richly analogical/metaphorical expression, the sophistication of thought, and the profusion of gods the hymns display, but Rig Veda 1.164.46 explains: "Truth is one; the wise call it by many names." 
One name is Brahman. Another is Vāk (Speech), also known as Saraswatī, who has a thousand names, each foregrounding a special attribute (Prasoon 2009, pp. 163-164); and Speech is Brahman, as certain hymns suggest: The Richo Akśare verse (1.164.39), the Hymn of Knowledge - the Jñana Sükta (10.71) — the Bāghāmbhṛni hymn to Vāk (10.125), and other hymns about the nature and power of speech hold the seeds of Vedānta philosophy within them, which is integral to the Vedic view of speech and communication. Indeed, the Richo Akśare verse appears verbatim in the Shvetāshvatara Upanișad as verse 4.8 , thus asserting the vedāntic stance of this Vedic verse. Riși Bāghāmbhṛ̣i, in her hymn to Vāk, where she identifies fully with the goddess Vāk, describes the depth, breadth, and power of speech as the all-inclusive substance and governor of the universe. She proclaims:

... I spread through all beings and touch this heaven with my body (7)

I breathe forth like the wind, giving form to all created worlds; beyond the heaven, beyond this earth (am I), so vast am I in greatness. (8)

This may be as close to a portrait of Brahman as word can convey. The hymn demonstrates both the direct experience and the conscious awareness that "I am That," thus validating Bāghāmbhṛni's mature state of Brahman consciousness, the fulfillment of Vedānta.

She proclaims that her source, the source of speech, is in the transcendental field of consciousness: "My birthplace is in the midst of the waters" (10.125.7), a frequently-used metaphor for the ocean of consciousness, the imperishable wholeness. 
This metaphor also appears in 1.164.42, where the word akśara, imperishable - which also means letter, word, and sound - is used to mean "water," playing with the obvious association of speech and its imperishable source (MonierWilliams, 2014). Vāk proclaims that "He who sees, who breathes, who hears what is spoken, does so through me; those who are ignorant of me perish" (4). Thus, transcendental consciousness is the basis and means of understanding, the ability to be conscious of anything, to experience and, indeed, to live and thus cannot be neglected to good effect.

The principle of a transcendental level of speech is embedded in the Vedic worldview and ubiquitous in the literature, implicitly or explicitly, but levels-of-speech theory has its first extant mention in the hymn that contains the Richo Akśare verse: Rig Veda 1.164.45 proclaims that there are four levels of speech; men see (/hear) just one level; the other three are hidden (Padoux, 1990, p. 167). Speech is both manifest and un-manifest, like the universe. Indeed, according to this hymn and later theory, speech virtually is the universe; speech is Brahman. By the fifth century C.E., sage Bharțhari helpfully elaborated levels-of-speech theory in his Vãkyapadīya, building on long-standing tacit theory. He named the levels and described them, for the hymn names only the transcendental level, Parā.

The figure below depicts the mind as an ocean of consciousness. The arrow labeled W2 shows the full range of the mind - and of speech - from its active surface expressions to its silent depth. Maharishi Mahesh Yogi (1967) explains that thoughts bubble up from Para in the depths of the mind, come to conscious awareness, and burst forth as speech. The 
most-expressed level is Vaikharī, speech one can hear or read, the range indicated by the short arrow labelled W1, indicating the small range of speech theorized in Western theory. W2 represents the full range of mind/speech theorized in the Vedic literature (Maharishi, 1967 p. 470). Deeper than the Vaikharī levelis Madhyamā, silent speech-in-thought. Less familiar is the deeper level, Pasyantī. "Pasya" means "see." On this fine feeling level, the impulse of thought is sensed as a gestalt, all in a glance, more felt than articulated. Unlike the linear flow of language word after word on the Madhyama level of the mind, Pasyantī is nearly free of space-time (Coward \& Goa, 2004 p.38). Beyond Pasyantī lies Parā, infinite silence.

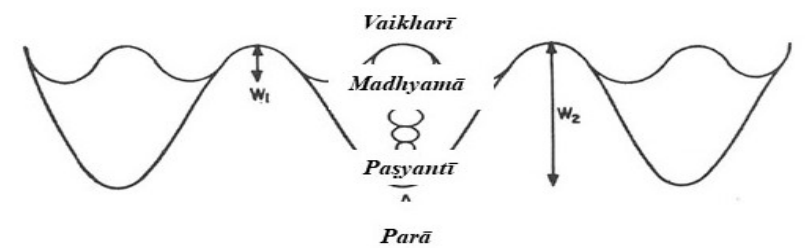

Figure: The Levels of Speech (adapted from Maharishi, 1967 p.470)

Yet, as the Richo Akśare verse reveals, Parā is also dynamic, a reservoir of creative intelligence. The verse proclaims:

The verses of the Veda exist in the transcendental field, Which the devas, responsible for the whole universe, inhabit.

He who is not open to this field, what can the verses accomplish for him? 
Those who know this are established in evenness.

The silence is lively with virtual sound, the devas, mantra, which, vibrating in different frequencies, structure and govern the universe. This aggregate of all the laws of nature is RtaBrahman, and the verses are composed of this field; one must open conscious awareness to this field to benefit from their content. Implicit in the verse is a call to action, the duty, the sanātana dharma to attain knowledge/experience of the Reality so that wholeness may be known and lived.

Sage Bharțhari describes the Reality similarly, starting his Vākyapadīya by affirming: "Brahman ... whose very essence is the Word, who is the cause of the manifested phonemes, ... from whom the creation of the world proceeds" (1.1). Similarly, for Indian music theory, the universe is nothing but spanda, pulsations of the sonic absolute, Brahman: $\mathrm{He}$ is the rasa that the artist strives to convey to give the viewer a taste of Brahman (Ubhyakar in Desai, 2009 disk one, 00:09:30 \& 01:56). For some, such a perspective may sound fanciful; however, recent advances in physics tend to validate the Vedic view of the universe.

Though not part of Western language theory, this unitary vision does bear striking resemblance to the way that string theory of quantum physics describes the universe. Ina TED talk, Brian Greene: Making Sense of String Theory, the physicist explains that the universe according to string theory consists of "a huge number of ... filaments of vibrating energy, vibrating in different frequencies. Different frequencies produce different particles. The different particles are responsible for all the richness in the world around us. And there you see unification" (Feb. 2005, 8:57-14:54). This 
seems a close paraphrase of the Richo Akśare verse; however, in a later interview Greene (Jan. 30, 2014) excludes consciousness, arguing that the purview of physics is the physical universe alone, which he has nevertheless described as non-physical virtual vibrations. But the world's most-cited string theorist, John Hagelin (Dec. 8, 2007), argues for a conscious universe, which he describes as a symphony of creative intelligence, and, he says, "That's what we're made of." Hagelin's assertion echoes the Upanișadic Mahāvākyas: "I am the totality" aham brahmāsmi, "Thou art that" tat tvam asi, and "All this is that" sarvam khalv idam brahma, and "that totality, wholeness, is consciousness" prajñānam brahma. Indeed, the Katha Upanișad proclaims, "Manifest diversity is unmanifest - there is nothing else" (2.1.11). It bespeaks the imperative to open one's awareness to this field as the verse proclaims in order to benefit from the total potential of Natural Law available deep within. This will be the source and fulfillment of eloquence. Thus, the aim of Vedānta, to realize Brahman, brings practical side-benefits that are essential to living the full value of life and make the most of speech.

The Hymn of Knowledge, the Jñana Sükta of the Rig Veda (10.71) makes the same point, but helpfully describes just how one's state of consciousness affects eloquence and success in everyday life. First, the hymn identifies "the best part of Speech" as Brihaspati, the guru of the gods (Rig Veda8.100.10 in Timalsina, 2009, p. 403), who is associated with Brahman, with wisdom, and with speech (Griswold, 1999 pp. 172 \& 174). In richly metaphorical terms, it proclaims that, attuned to "the best part of Speech" (1), which is structured in transcendental consciousness, Para $\bar{a}$,... "then 
friends know friendship; good fortune is placed upon their word (2).... They do not exclude him from (the society of) the powerful (in knowledge)" (5). But one who has not duly cultivated "the friendship (of Speech) ... wanders with an illusion that is barren, bearing Speech that is without fruit, without flowers" (5). The hymn explicitly elaborates on the consequences of failing to cultivate the "friendship of Speech":

He who has abandoned the friend who knows the duty of a friend, in his speech there is not a particle (of sense); what he hears, he hears amiss; for he knows not the path of righteousness (6)

...devoid of wisdom, attaining Speech, having sin-producing (Speech) (9)

Intelligence and understanding, then, depend on having awareness open to the full range of speech/consciousness. Bhartrihari writes that when awareness is open to the deep level of speech Pashyanti, then the full meaning of words stands revealed (in Coward and Goa, 2004, p. 40) but that when conscious awareness is limited to a surface level of perception, then understanding is limited (p. 41). He explains:

When the absolute [transcendental Para $\bar{a}$ ] is awakened, and meanings are manifested through words, then the knowledge and power that is intertwined with consciousness can be clearly perceived and known. Because consciousness is of the nature of wordmeaning, the consciousness of any sentient being cannot go beyond or lack word-meaning. (qtd. in Coward, 1989, p. 167) 
In other words, "knowledge is structured in consciousness," as Maharishi Mahesh Yogi summarizes the RichoAkśare verse - a sutra, if you will. Meaning/knowledge is everywhere available; lack of understanding is only due to "ignorance or absent mindedness [that] obscure[s] the meaning inherently present" (Bhartrihari qtd. in Coward, 1989 , p. 167). Thus, what had come to be seen as a monastic pursuit, the attainment of the highest state of knowledge/experience, is proclaimed in the hymns to be a requirement for living the full value of life in society.

But what is "the duty of a friend" which the Jñana Sükta (6) enjoins? Clearly, it argues that attunement to Parā is crucial, yet the hymns are not clear on the means of gaining that desirable state. The Jñana Sükta seems to suggest that yajña plays a role: "(The wise) reached the path of Speech by sacrifice, they found it centred in the Rishis" (3), but this line also seems to direct attention beyond the yajña to the state of consciousness, the enlightenment of the rșis who produced the verses of the rite. Moreover, the Richo Akśare verse states flatly that the verses are ineffectual without the requisite consciousness to enliven them.

Method of attainment may well be tacitly assumed in the hymn due to the long-standing tradition of Yoga as well as the revered role of the guru in Vedic civilization as mentor for the process of enlightenment. Indeed, Yoga has been considered an essential element of practical training and success in a wide variety of fields, not only communication, but also others ranging from dance to medicine (Maharishi, Aug. 12, 1971, p. 195; Gautama in Bhattacharyya, 2010 p. 87; Kothari and Om 00:55:59; Chatterjea, 1996 p. 73). At the same time, 
diverse fields of knowledge claim that their practices are designed to lead to mokșa. Bhartrihari made that case for the study of grammar in the Vākyapadīya, and Patañjaliposited that "the grammarian is a Yogi whose inward vision enables him to look within to see the eternal flow of pure consciousness" (in Chaitanya, 1962 p. 53). Gautama's Nyāya method of debate similarly states its ultimate goal as mokșa, just as Bhārata Nātyaśāstra declares the arts to be a means to know Brahman. In turn, all of these disciplines take Yoga as integral to attaining their ultimate goal and extoll it as the direct and efficient path. Thus, the duty that the Jñana Sükta (6) enjoins would be the practice of Yoga. If the affordance of Yoga were not assumed, the Sanskrit proverb, "No leaves, no branches without the root," would dismay rather than inspire.

Steeped in the guru-śisya tradition, Maharishi Mahesh Yogi (Aug. 12, 1971) takes the Richo Akśare verse as a call to learn and practice Yoga, meditationthat allows the mind to transcend the surface level of the mantra (word) and experience its source because, he says, "This hymn itself very clearly brings to light that the Veda is not knowable on the basis of the words, it is knowable on the basis of the foundation of all words, that basic unmanifest sound, pure being, consciousness. In that material, the words of the Veda are structured" (p. 201). Patañjali described the letters (akśara) of the alphabet of which the hymns are composed as "not mere phonetic types, but glowing sparks of Brahman illuminating the entire sphere of existence" (Chaitanya, 1962 p. 53). Maharishi (1967) explains the significance to human life: 
The conscious mind becomes powerful when the deeper levels of the ocean of mind are activated in the process of Transcendental Meditation, which leads the attention from the surface of the conscious mind to the transcendental field of Being. The process of diving within is the way to become established in Yoga. (p. 136)

Therefore, Maharishi (2019) takes Yoga to be a necessary complement to the practice of yajña, which the Jñana Sükta indicates plays an important role in living the full value of life $(10.71 .3,10 \& 11)$. However, if yajña were effective, wars, disease, and misfortune could not endure; health, prosperity, and harmony would prevail. But, Coward and Goa (2004) point out, that if "the pashyanti level is obscured from 'sight,' then the uttering of the mantra will indeed seem to be an empty exercise" (p. 40). Maharishi (in Katz, 2011) posits that the speaker must be established so "the whole speech of his is the vibrant consciousness, vibrant Absolute. ... An unenlightened man [sic], repeating the same thing, does not produce those ... ripples of the full value of knowledge" (vol. 2, p. 245), much as the Jñana Sükta suggests. Yoga and yajña are complementary.

The hymn moreover proclaims that cultivating "friendship" with this field results in "mental apprehensions which are conceived by the heart (of the wise)," in other words, the wise have attained a mature state of intelligence that can "wander at will in the meanings of the Veda" (8). It is precisely such a ripe intellect that is capable of activating the power of the Mahāva $\bar{k} y a$, the final stroke of teaching necessary to catalyze the state of knowledge called Brahman consciousness (Katz, 
2011, vol.1 p. 54 \& pp. 315-318). In other words, the message that "Thou art that," results in final realization when the experiencer is ripe to hear it fully; the communication can then bear the intended fruit. Thus, Vedānta and Yoga are complementary (see Maharishi, 1967 p.473).

In the final analysis, the seeds of Vedānta are evident in the Richo Akśare verse and the Jñana Sükta, which proclaim the practical value of Vedāntaphilosophy and the ultimate fruit of communication. They proclaim the " $\mathrm{X}$ factor" for eloquence, the crucial condition for winning all treasures both earthly and divine, a process that entails moksa and unlocks the shakti of all speech, the sacred speech of yajña as well as the speech of everyday life in all its manifestations. Maharishi (Jan. 17, 1975) foregrounds the practical value of Vedānta when he explains that, "When one is using speech and one is well connected to the source of speech, which is unbounded, infinite, eternal, all comprehensive, then speech will always be flowering into those values of unboundedness and widest comprehension and greatest focus, which will accomplish the maximum value of communication" ("Enlivening the Full Range of Life" p. 155). His words, in effect, summarize the hymns, which, I have argued, implicitly enjoin the practice of Yoga, of opening the awareness to the full range of the mind - practical Vedānta for living total knowledge and attaining the goals of communication, earthly and divine for immediate practical fulfillment and for realization of the ultimate goal which the Vedic worldview envisions. 


\section{References}

Adhikary, N. M. (2014). Re-orientation, Ferment and Prospects of Communication Theory in South Asia. China Media Research 10(2), 24-28. Communication and Mass Media Complete.

Bhattacharyya, S. (2010). Development of Nyāya philosophy and its social context. New Delhi, India: Centre for Studies in Civilizations. Print. In. D.P. Chattopadhyaya (Gen. Ed.). History of Science, Philosophy and Culture in Indian Civilization. Vol. 3 part 3.

Bryant, E. F. (2009). The Yoga Sūtras of Patañjali: A new edition, translation, and commentary with insights from the traditional commentators. NY: New Point Press.

Chaitanya, K. (1962). A new history of Sanskrit literature. Bombay: Asia Publishing House.

Chatterjea, A. (Spring, 1996). Training in Indian classical dance: A case study. Asian Theatre Journal 13(1), 68-91. Stable URL: http://www.jstor.org/stable/ 1124303 JSTOR Journals.

Choudhuri, U. (2006). Vag vai Saraswati. In S. Kumar (Ed.). Veda as Word (pp. 56-63). New Delhi: New Delhi: Special Center for Sanskrit Studies, Jawaharlal Nehru University: D.K. Printworld.

Coward, H. G., \& Goa, D. J. (2004). Mantra: Hearing the divine in India and America. (2nd ed.). NY: Columbia University Press.

Coward, H. G. (1989). The meaning and power of mantras in Bhartrhhari's Vākyapadìya. In H. P. Alper (Ed.). Mantra (pp. 165-176). Albany, NY: State University of New York Press. 
Desai, G. (2009). Raga unveiled: The history and essence of North Indian classical music. [DVD]. Gita Desai \& Mukesh Desai (Producers).

Egenes, T. (2015). Introduction. In V. Katz \& T. Egenes (eds. and trans.). The Upanishads, a New Translation (pp. 1-28). New York: Tarcher/Penguin.

Greene, B. (Feb. 2005). Brian Greene: Making sense of string theory. TED talk. YouTube. Uploaded April 23, 2008.

---. (Jan. 30, 2014). Reimagining the cosmos. Interview by Krista Tippett. On Being. [radio series episode, online transcript]. National Public Radio. https://onbeing.org/programs/briangreene-reimagining-the-cosmos/

Griswold, H.D. (1999). Religion of the Rigveda. [Rpt.] New Delhi: Motilal Banarsidass Publishers. Google Books.

Hagelin, J. S. (Dec. 8, 2007). John Hagelin Ph.D. on consciousness \& superstring unified field theory. 2 parts. YouTube.

Katz, Vernon. (2011). Conversations with Maharishi: Maharishi Mahesh Yogi speaks about the full development of human consciousness. 2 vols. Fairfield, IA: Maharishi University of Management Press.

Kothari, D. (director) \& Om R. (director and writer). (Jan. 2014). History of yoga. [DVD] Mumbai: Vishuddhi.

Maharishi Mahesh Yogi. (1967). Maharishi Mahesh Yogi on the Bhagavad-Gita: A new translation and commentary, chapters 1 to 6. NY: Penguin.

---. (Aug. 12, 1971). The relation between name and form in the Veda. [Video transcript] Humboldt State University, Arcata, CA. IAASCI. In Maharishi Mahesh Yogi, R. F. OrmeJohnson \& S. K. Andersen (Eds.). The flow of 
consciousness: Maharishi Mahesh Yogi on literature and language 1971 to 1976 (pp. 189-203).

---. (Jan. 17, 1975). Enlivening consciousness, the common basis of all languages: The ground for perfect communication. [Videotaped lecture]. Vitznau, Switzerland. IAASCI. In Maharishi Mahesh Yogi, R. F. Orme-Johnson \& S. K. Andersen (Eds.). The flow of consciousness: Maharishi Mahesh Yogi on literature and language 1971 to 1976 (pp. 149-155).

---. (2010). The flow of consciousness: Maharishi Mahesh Yogi on literature and language 1971 to 1976. (R. F. Orme-Johnson, \& S. K. Andersen, Eds.). Fairfield, IA: ConsciousnessBased Books-Maharishi University of Management Press.

---. (2019). Overview. Maharishi Yagya Program. Retrieved from www.maharishiyagyaprogram.eu

Maharishi University of Management. Introduction. (2018). Consciousness-based education. Maharishi University of Management Press.

Monier-Williams, M., Sir. Monier-Williams 1872 dictionary. (2014 ed.) [Sanskrit-English Dictionary. Oxford University Press (1872).] Cologne Digital Sanskrit Dictionaries. http://www.sanskrit-lexicon.unikoeln.de/scans/MW72Scan/2014/web/index.php

Padoux, A. (1990) Vāk: the concept of the word in selected Hindu tantras. J. Gontier (Trans.). Albany, NY: State University of New York Press.

Prasoon, Shrikant. (2009). The creator of universe Ma Shakti. New Delhi: Hindology Books. Google Books.

Rig-Veda sanhita - a collection of ancient hindu hymns, constituting part of the seventh and eighth ashtaka of the Rig-Veda. H.H. Wilson (Trans). W.F. Webster (Ed.). (1888) 
London: Trübner \& Co. Google Books.

https://books.google.com Rpt. (c.1978.) Rig Veda Tenth

Mandala. [Livingston Manor, NY]: Age of Enlightenment Press.

Sandness, I. (2007) On Ratá and Bráhman: visions of existence in the Rg-Veda. Annals of the Bhandarkar Oriental Research Institute, vol. 88, 61-80. Stable URL:

http://www.jstor.org/stable/41692085

The Upanishads, a New Translation. (2015) V. Katz \& T. Egenes (Eds. and trans.). New York: Tarcher/Penguin.

The Vākyapadīya of Bhartrhari with the vrtti: chapter 1 English translation. (1965). Iyer, K. A. S. (Ed. \& Trans.). Poona, India; Deccan College.

Timalsina, S. (2009). The Vedic mantras. In Brill's encyclopedia of hinduism. Vol.2. K. A. Jacobsen (Ed.-in-Chief), H. Basu, A. Malinar, \& V. Narayanan (Assoc. Eds.). Leiden, Neth.; Boston, MA: Brill. 400-415. In series Handbook of Oriental Studies, Sect. 2, India. J. Bronkhorst \& A. Malinar (Eds.).

\section{Author Note:}

Anne Melfi completed her Ph.D. in Rhetoric and Composition at Georgia State University. Her dissertation research on Understanding Indian Rhetoric on Its Own Terms: Using a Vedic Key to Unlock the Vedic Paradigm, on which this paper is based, was supported by a dissertation grant from the Georgia State University College of Arts and Sciences. Correspondence concerning this article should be addressed to Anne Melfi, P.O. Box 401, Laupahoehoe, HI 97674, USA. annemelfi@gmail.com 